\title{
Formandens årsberetning 16. november 1992
}

Grundtvig-selskabets årsmøde 1991 blev afholdt 25 oktober 1991 i Vartov, Farvergade 27, København K. Ved årsmødet talte professor dr. phil. Ole Feldbæk om Dansk identitetshistorie i det 18. århundrede, og docent Flemming Lundgreen-Nielsen om Grundtvig og Danske Samfund.

På årsmødet blev Henning Høirup, Erica Simon, Peter Balslev-Clausen, Leif Grane og Jørgen I. Jensen genvalgt til styrelsen. Christian Thodberg og William Michelsen blev genvalgt til forretningsudvalget.

Året 1992 har været præget af en række initiativer taget af den kreds af Grundtvig-forskere, der står bag Center for Grundtvig-Studier på Aarhus Universitet. 13. januar 1992 blev der således på Aarhus Universitet afholdt et endagsseminar om Grundtvig i internationalt perspektiv med forelæsninger af A.M. Allchin og K. Stevenson, ligesom der 24. april blev afholdt et seminar med en lang række bidrag om den grundtvigske historieskrivning i 19. og 20. århundrede. 3.-6. september blev der ligeledes på Aarhus Universitet $\mathrm{i}$ anledning af det teologiske fakultets 50-års jubilæum i samarbejde med Det danske Kulturinstitut afholdt en international konference om »Grundtvig Denmark - Europe, Nations in Relationship«. Dertil kommer, at A.M. Allchin 11. september 1992 blev udnæunt til æresdoktor ved Aarhus Universitets årsfest.

Af årets Grundtvig-litteratur kan foruden »Grundtvig-Studier «, der endnu engang har samlet et repræsentativt udvalg artikler om Grundtvig, nævnes Helge Grells »England og Grundtvig o og Eva Meiles studiebog om Grundtvigs salmedigtning, »Plant en lilje $\ll$. Hertil kommer, at den tyske trebinds udgave med oversættelser af Grundtvig-tekster skrider planmæssigt frem, og at man er ved at lægge sidste hånd på et bind med artikler om Grundtvig på engelsk.

Den norske afdeling af Grundtvig-selskabet er fortsat fuld af energi og præget af mange initiativer. Afdelingen, der med regelmæssige mellemrum udsender et eget meddelelsesblad, ledes handlekraftigt af Kirsti Aasen (formand) og Dag Løkke. Forbindelsen med den norske afdeling varetages fortsat af Christian Thodberg. 
Grundtvig-Selskabet er i sin virksomhed ikke alene afhængig af medlemmernes kontingentbetaling, men også af støtte fra forskellige fonds, N.F.S. Grundtvigs Fond, Statens Humanistiske Forskningsråd og Kirkeligt Samfund, en støtte for hvilken der her ved årsmødet skal lyde en varm tak. En tak skal også lyde til Elisabeth Katzmann og Inger Rasmussen, der på Kirkeligt Samfunds kontor i Vartov står for den daglige ekspedition af Grundtvig-Studier og Selskabets korrespondance i øvrigt.

Peter Balslev-Clausen 